\title{
Interpreting Empirical Estimates of the Effect of Corporate Governance
}

\author{
Yair Listokin, Yale Law School
}

Empirical studies of corporate governance address potential endogeneity problems, but fail to place endogeneity in the context of a model and ignore the possibility of disparate treatment effects across companies. This paper tackles these defects. The model and analysis in the paper demonstrate that: (1) Valid and positive estimates for the effect of governance can only arise if there is random variation in governance and governance is systematically underproduced, or governance is chosen randomly without bias and the randomness under study concerns a subpopulation with below-average governance. (2) Governance models that correct for endogeneity using subsamples of firms, fixed effects, or instrumental variables estimates focus on subpopulations of companies that may have different responses to a governance treatment than the average firm. (JEL K22, G34)

\section{Introduction}

Corporate law and corporate finance have taken an increasingly empirical turn. Law reviews and finance journals are replete with empirical studies of the effect of corporate law or other sources of governance on corporate performance. This is a good thing. Theoretical arguments about the value of staggered boards or outside directors mean little without hard evidence about the size of these costs and benefits.

I thank Ian Ayres, Anne Case, John Donohue III, Daniel Ho, Roberta Romano, Benjamin Sachs, and an anonymous referee for helpful comments and discussions. All errors are my own.

Send correspondence to: Yair Listokin, Associate Professor, Yale Law School, PO Box 208215, New Haven, CT 06520-8215, USA; E-mail: yair.listokin@yale.edu.

American Law and Economics Review

doi:10.1093/aler/ahn005

Advance Access publication April 16, 2008

(C) The Author 2008. Published by Oxford University Press on behalf of the American Law and Economics Association. All rights reserved. For Permissions, please e-mail: journals.permissions@oxfordjournals.org 
However, these empirical studies only have value for policy to the extent that empirical estimations provide unbiased and appropriately understood estimates for the parameters of interest. Most prominently, the studies must account for endogeneity problems. For example, companies with staggered boards are different in many unobservable ways from companies without staggered boards (Bebchuk, Coates and Subramanian, 2002; Bebchuk and Cohen, 2005). It is therefore extremely difficult to attribute differences in takeover probabilities associated with firms with and without staggered boards to the staggered board, rather than some other factor. Many scholars are aware of the endogeneity concern and take steps to address it (Daines, 2001; Gompers, Ishii, and Metrick, 2003; Bebchuk and Cohen, 2005).

To this point, however, the treatment of endogeneity has been inadequate. ${ }^{1}$ There has been no model of the corporate governance process that carefully specifies sources and effects of potential endogeneity problems. The absence of a model has exacerbated another flaw of the corporate governance literature's treatment of endogeneity. When firms respond to corporate law and governance heterogeneously-i.e., when a governance mechanism affects one firm differently from another-then the cures for endogeneity, such as instrumental variables techniques, subsample estimates, or fixed-effects estimators, generate estimates of the effect of various governance strategies for a select group of firms. The relationship of the estimates derived for these subgroups to the average treatment effect (ATE) of a policy is the subject of an extensive literature in econometrics and labor economics (Imbens and Angrist, 1994; Heckman and Vytlacil, 2005; Heckman, Urzua, and Vytlacil, 2006) that has to this point been ignored by the corporate law and governance literature as well as in empirical legal studies, more generally.

This paper addresses these flaws. By developing a model of governance, the paper clarifies the successes and defects of the corporate governance literature in estimating the impact of many levers of corporate governance. The model allows us to specify the conditions under which scholars may interpret empirical results as supporting conclusions, such as "corporate law

1. This paper does not attempt to provide an exhaustive review of potential flaws in corporate governance studies. For example, there is a rich literature discussing the calculation of valid standard errors in financial data sets that is not treated here. See, e.g., Peterson (2007). 
involves a race to the bottom between states" or "staggered boards reduce value." The only way to credibly find a negative impact for a staggered board is to find some variable that generates random variation in governance for a set of firms that overuse staggered boards.

The model also provides a lever for interpretation of corporate governance estimates when firms respond to corporate law and governance heterogeneously. In many cases, the subpopulation of firms induced to change governance by a random variable will be very different from the population of interest for policy. For example, a firm that is induced to choose a staggered board by some accident of history may well have a different response to a staggered board than the average firm, even after controlling for other factors. The paper examines how this heterogeneity affects the interpretation of many popular corporate law and governance estimation techniques. Instead of attempting to directly estimate the ATE for all firms, which is a generally unattainable goal, the econometrics literature advocates estimates local average treatment effects (LATE) or marginal treatment effects (MTE) for several different subpopulations. When a proposed policy affects firms with similar characteristics to those firms for whom a valid LATE has been obtained, then extrapolation of the LATE estimates to estimate the policy response deserves greater credence than general extrapolations of LATE to very different populations (Imbens, 2007a).

\section{Estimating Treatment Effects in Corporate Governance}

\section{Treatment Effects Framework}

Most empirical studies seek to determine the "treatment effect" of a certain treatment variable on another variable of policy interest (Angrist, 2007). For example, a study examining staggered boards would search for the treatment effect of having a staggered board on the value of the company, or on the probability that the company will be taken over. Formally (following Angrist, 2007), let $D_{i}$ be a dummy variable indicating whether company $i$ receives a treatment (e.g., a staggered board), ${ }^{2}$ let $Y_{1, i}$ be the outcome variable of interest when the treatment is received, such as the value of

2. For simplicity, I focus on a discrete treatment variable. Most variables of interest in corporate law, such as state of incorporation, staggered board, poison pill, or overall 
company $i$ with a staggered board, and let $Y_{0, i}$ be the outcome when the treatment is not received, such as the value of company $i$ without a staggered board. The treatment effect on $i$ is therefore $Y_{1, i}-Y_{0, i}$.

Treatment effects vary across experimental subjects. When this occurs, the treatment effect is termed heterogeneous. The effect of a staggered board on one company's value differs from a staggered board's effect on another company's value. Because it is generally difficult (or impossible) to determine the treatment effect of a treatment for each experimental subject $\left(Y_{1, i}-Y_{0, i}\right.$ cannot be known for each $i$ because we only observe either $Y_{1, i}$ or $Y_{0, i}$ for any $i$ ), researchers typically attempt to estimate the ATE for all subjects in a population. The ATE can be expressed as $E\left[Y_{1, i}-Y_{0, i}\right]$, where $E$ is the mathematical expectation operator. In the staggered board context, the empirical researcher seeks to determine the average effect of a staggered board on corporate value. While the ATE is a frequently used parameter of interest for the empirical researcher, the ATE is not always the parameter of greatest interest. Some policy interventions effect subpopulations that may respond differently to a treatment variable than the average population. For example, if one is considering outlawing staggered boards, then the treatment effect of interest is the effect of eliminating staggered boards for companies that already have them $\left(E\left[Y_{1, i}-Y_{0, i} \mid D_{i}=1\right]\right),{ }^{3}$ since companies with staggered boards are the only companies that will be affected by the policy change. This effect (often called the average treatment effect on the treated or ATET) may be different than the ATE. Indeed, we might think that firms that choose staggered boards to be less negatively affected by staggered boards than firms that reject staggered boards. Alternatively, one might suppose that the only firms that destagger are those in which management is so entrenched that the staggered board does not matter. In either case, the ATET differs from the ATE. Another treatment effect of interest is the MTE, which is the treatment effect of a variable for those on the margin of experiencing or not experiencing the treatment. The MTE will also generally be different than the ATE or ATET. For example, firms at the margin of having or not having

governance are discrete treatments. Similar conclusions, with more notational complexity, apply when a continuous treatment variable is used.

3. This expression compares the value of a particular firm, when it has a staggered board and under the counterfactual of taking the staggered board away, given that the firm currently has a staggered board. 
a staggered board will be differentially affected by a staggered board than the average firm (ATE) or the average firm that chooses the staggered board (ATET). ${ }^{4}$

\section{Corporate Governance Literature}

Over the last decade, a series of important empirical articles have evaluated the impact of many levers of corporate governance on firm value and performance. The majority of these papers share an underlying empirical methodology. They collect data on firm value and on corporate governance measures and exploit variation in governance within and across companies to measure governance's effect on value. To illustrate, Daines (2001) regressed Tobin's $q$, a measure of value added by a firm, on state of incorporation and a long list of control variables and found that Delaware law raises firm value by 5-7 percent. These results were criticized by Subramanian, among others (2004), who found that the Delaware effect disappeared in years following Daines' study and that alternative treatment of some variables reduced the size of the Delaware effect.

Other studies attempt to determine the impact of staggered boards on corporate value and performance (Bebchuk, Coates, and Subramanian 2002; Bebchuk and Cohen 2005). ${ }^{5}$ Bebchuk and Cohen find that staggered boards are associated with a reduction in Tobin's $q$ by 15-20 percent (p. 423) after controlling for many other factors. Still others attempt to measure the aggregate value of all forms of governance. In one of the most wellknown studies, Gompers, Ishii, and Metrick (2003) develop a composite measure of governance that includes many aspects of governance, such as the presence or absence of a poison pill, staggered board, and state antitakeover statutes, among many others. They find that their composite measure of governance is associated with an 8.5 percent increase in annual returns. Many papers have attempted to refine, explain, or undermine the Gompers, Ishii, Metrick results. (e.g., Bebchuk, Cohen, and Ferrell, 2004; Chi, 2005; Cremers and Nair, 2005; Core, Guay, and Rusticus, 2006). For

4. See Heckman and Vytlacil (2001) for an illuminating discussion of different treatment effects of interest.

5. Many other governance topics have been examined, including the effect of independent directors on value (see studies reviewed in Bhagat and Black, 2002) and the effect of board of director size on firm value (see studies reviewed in Eisenberg, Sundgren, and Wells, 1998). 
example, Core, Guay, and Rusticus (2006) show that the GIM results cannot be attributed to incorrect investor expectations of the performance of wellgoverned firms, while Bebchuk, Cohen, and Ferrell (2004) argue that the bulk of the governance effects found in GIM can be attributed to just a few governance variables, including staggered boards and poison pills.

If the estimates presented in these papers can be interpreted as treatment effects, then academic research reveals that certain governance practices have large positive effects on firm performance. This knowledge, if implemented by corporations, could have enormous impacts on the economy. Few areas of academic research can compete with discovering a treatment that can improve firms' annual returns by 8.5 percent. A careful examination of these studies' identification strategies is therefore warranted.

Returning to the staggered board example, the primary specification would compare the value (e.g. Tobin's $q$ ) of firms with and without staggered boards. Formally, $E\left[Y_{i} \mid D_{i}=1\right]-E\left[Y_{i} \mid D_{i}=0\right]$. All of these papers, however, realize that a simple comparison of values for firms with and without staggered boards does not provide an accurate estimate of the treatment effect of staggered boards. Firms choose whether to have a staggered board or not. Therefore, firms with staggered boards may be systematically different than firms without staggered boards. Differences in value between firms that have or do not have a staggered board may be due to the staggered board, or they may be due to other systematic differences between the firms. Formally,

$$
\begin{aligned}
{\left[E \left[Y_{i} \mid D_{i}\right.\right.} & \left.=1]-E\left[Y_{i} \mid D_{i}=0\right]\right]=\left[E\left[Y_{1, i} \mid D_{i}=1\right]-E\left[Y_{0, i} \mid D_{i}=0\right]\right] \\
& =E\left[Y_{1, i}-Y_{0, i} \mid D_{i}=1\right]+\left\{E\left[Y_{0, i} \mid D_{i}=1\right]-E\left[Y_{0, i} \mid D_{i}=0\right]\right\} .
\end{aligned}
$$

The difference in value between firms with and without staggered boards is the sum of the ATET and a bracketed endogeneity effect, $\left\{E\left[Y_{0, i} \mid D_{i}=\right.\right.$ $\left.1]-E\left[Y_{0, i} \mid D_{i}=0\right]\right\}$, due to the fact that the average value of the type of firms with staggered boards $E\left[Y_{0, i} \mid D_{i}=1\right]$ is different than the average value of firms without staggered boards, and these values would be different even if there were no such thing as staggered boards.

The papers are well aware of the endogeneity problem and respond in various ways. Indeed, many of the papers under study use all of the techniques described below to address endogeneity problems. To properly understand these methods, however, a model of the data-generating process that 
produces the observed variation in corporate governance is necessary. None of the papers provides such a model. A simple framework is therefore developed below and applied to the corporate governance studies described above.

\section{Models of Corporate Governance Decisions and Variations in Corporate Governance}

Consider a simple model of governance decisions. Suppose each unit of governance, $g$, for company $i$ yields net benefits $b_{i}(g)$. Assume that $b_{i}^{\prime}(0)>0$, meaning that going from no corporate governance to a small amount has at least some benefits for all companies, and $b_{i}^{\prime \prime}(g)<0$ - there are diminishing marginal returns on governance.

Each company chooses $g$ to maximize its value attributable to governance,

$$
\max _{g} b_{i}(g)
$$

yielding the first-order condition $b_{i}^{\prime}(g)=0$. Intuitively, a firm increases governance until the marginal benefit of a unit of governance, $b_{i}^{\prime}(g)$ is no longer positive. Let $g_{i}^{*}$ denote the optimal governance level for firm $i$.

Even with this simple model of corporate governance, a number of observations are possible. First, if $b_{i}(g)=b_{j}(g)$ for $i \neq j$, meaning that the net benefits of governance are the same for all companies, then all companies will have the same amount of governance, $g^{*}$, implying that there will be no variation in governance choices. Because we observe variation in governance, there must be something wrong with the model or the assumption that $b_{i}(g)=b_{j}(g)$.

\section{Model I}

One possibility is that governance is chosen through the model plus some symmetric mean-zero random perturbation $\left(\varepsilon_{i}\right), g_{i}=g^{*}+\varepsilon_{i}$. This would occur if a firm is trying to choose the optimal governance arrangement, but idiosyncratic disturbances prevent the firm from getting to this amount. Under these assumptions, all deviations from the average level of governance decrease value. For firms with below-average governance, increases in governance increase value and for firms with above-average governance, increases in governance decrease value. There would be no 
endogeneity bias, as the randomness of governance choices insures that $E\left[Y_{0, i} \mid D_{i}=1\right]=E\left[Y_{0, i} \mid D_{i}=0\right]$, or the continuous variable equivalent. Thus, a simple comparison of outcomes across firms with different governance arrangement yields the average treatment effect $\frac{1}{I} \sum_{i \in I} b_{i}^{\prime}\left(g^{*}+\varepsilon_{i}\right)$. Depending on the concavity or convexity of $b^{\prime}(g)$, the average treatment effect can be positive, negative, or zero. This corresponds to the "market efficiency" critique of corporate governance studies-if companies are choosing governance to maximize value, the ATE of studies of governance should be zero or near zero. Note, however, that a study examining variation in the subset of firms with the least governance would find a positive effect of governance and a study examining variation in firms with the most amount of governance would find a negative effect of governance.

\section{Model II}

Another possibility is that governance choices are systematically biased but vary randomly, that is $g_{i}=g^{*}+\varepsilon_{i}$, where $\varepsilon_{i}$ is a random variable with a positive or negative mean. This would occur if there remain idiosyncratic features affecting the governance choice, ${ }^{6}$ but market participants consistently overestimate or underestimate the value of governance, or other factors, such as principal-agent problems or ignorance, systematically bias governance choices. As in the case above, there is no endogeneity bias and a simple outcome comparison produces an estimate of the average treatment effect. If $E\left[\varepsilon_{i}\right]<0$ (governance choices are biased downward), then the estimated treatment effects will be positive. ${ }^{7}$ Because average governance choices are too low, more governance means higher asset values. A potential explanation for the source of Model I or Model II variation is examined in Model IV.

\section{Model III}

Alternatively (or additionally, all the models presented here may have an element of truth), firms could differ in their governance maximization

6. If there is no random variation in governance but there is bias, then there will be no variation with which to obtain treatment effects.

7. BCF (Cal. Law Review, 2002) argue that finding a positive effect implies that there must be selection bias. This model shows otherwise. So long as there is a plausible mechanism, biasing choices in one direction (e.g., ignorance or faulty expectations), then empirical studies may find positive effects without any implication of selection bias. 
decisions. That is, $b_{i}(g) \neq b_{j}(g)$. Different firms will have different needs for different types of governance and it therefore should be no surprise that what is optimal for one firm is not optimal for another. These differences in governance maximization may or may not be correlated with other attributes of the firm, e.g., firms in one industry may have more use for a staggered board than firms in another industry. Under these conditions, there will be variation in $g$ across companies. Because firms are maximizing, the true ATE should be zero-firms choose governance to maximize value. A simple comparison of outcomes across treatments, $E\left[Y_{i} \mid D_{i}=1\right]-E\left[Y_{i} \mid D_{i}=0\right]$ with this data-generating process, however, does not recover the ATE. To see this, suppose that $b_{i}(0)=b_{j}(0)$ and $b_{i}^{\prime}(g) \geq b_{j}^{\prime}(g)$ for all $g$. Because $b_{i}^{\prime}(0)>0$ for all $i$ and $b^{\prime \prime}<0$, this implies that $g_{i}^{*}>g_{j}^{*}$ and that $b_{i}\left(g_{i}^{*}\right)>$ $b_{j}\left(g_{j}^{*}\right)$. Thus, $E\left[Y_{i} \mid g=g_{i}^{*}\right]>E\left[Y_{i} \mid g=g_{j}^{*}\right]$. Intuitively, companies that benefit from more governance will (in this model) be worth more than companies that do not benefit, so comparing values across governance levels will lead to a positive treatment-effect estimate, in spite of the fact that the true ATE is zero-from company optimization. The endogeneity problem rears its head.

\section{Model IV}

A fourth model requires the introduction of a new variable $c_{i}$ to allow for principal-agent problems. Let $c_{i}$ represent the costs of a unit of governance to the manager and not the company, whose net benefits from governance continue to be determined by $b_{i}(g)$. Assume that the manager chooses governance to maximize her utility, which consists of the company's value from governance plus her own costs $\left(\max _{g_{i}} b_{i}\left(g_{i}\right)-c_{i} g_{i}\right)$. Without principal-agent problems, all companies would choose $g_{i}$ such that $b_{i}^{\prime}\left(g_{i}\right)=0$. Because of principal-agent problems (represented by $\left.c_{i}\right)$, the company instead uses governance to solve $b^{\prime}\left(g_{i}\right)=c_{i}$.

In Model 4 with $b_{i}(g)=b_{j}(g)$ for $i \neq j$, differential managerial aversion to governance (variation in $c_{i}$ ) causes all variation in governance. There will be heterogeneity in the effect of governance in spite of the fact that the benefits of governance are the same for all companies. Attempts to identify the ATE from variation in governance, $E\left[Y_{i} \mid D_{i}=1\right]-E\left[Y_{i} \mid D_{i}=0\right]$ may or may not be valid. The ATE estimate will be valid if $c_{i}$, the manager's cost of a unit of governance, is uncorrelated with the value of the company. If this is true, then differences in $c_{i}$ will cause differences in $g_{i}$ that cause 
differences in value exclusively through $b\left(g_{i}\right)$, allowing identification of the ATE. If $c_{i}$ is distributed randomly across companies and has mean zero, then Model IV is equivalent to Model I. If $c_{i}$ is distributed randomly across companies and has a positive mean, then Model IV is equivalent to Model II. If the costs of governance to the manager is correlated with corporate value, a likely possibility given that governance might be more costly for bad managers, then the ATE cannot be identified because $E\left[Y_{0, i} \mid D_{i}=1\right.$, low $\left.c_{i}\right] \neq$ $E\left[Y_{0, i} \mid D_{i}=1\right.$, high $\left.c_{i}\right]$. The estimate derived from simple comparison of outcomes across treatments would be biased due to omitted variable bias.

This modeling exercise yields the following conclusions. Simple comparison of outcomes for companies with different treatments, such as comparing Tobin's $q$ for companies with and without staggered boards or Delaware incorporation, yields valid and positive estimates of true treatment effects only if governance variation is random and governance is systematically underdesired or if managerial differences in costs of governance are uncorrelated with value of a corporation. ${ }^{8}$ All of these possibilities are difficult to believe, meaning that simple comparisons of value across governance choices generally yield invalid estimates of treatment effects.

\section{Interpreting Empirical Techniques for Estimating the Effect of Governance}

Although the empirical papers examined here do not develop a model of the process generating the observed variation in governance choices, they all appreciate the endogeneity problem. Indeed, most of the studies rely on several techniques to mitigate the endogeneity bias problem.

\section{Control Variables}

All the studies presented above include a host of control variables in a linear regression technique. The purpose of control variables is straightforward. While firms with staggered boards may be different than firms without staggered boards, the difference between these firms may be explainable by the linear impacts of other variables. In this case, we

8. This is not to say that there is no random variation in governance, but rather that some of the variation is nonrandom. When there is some nonrandom variation, naive estimates of the ATE will be biased as shown in Model III. 
can "control" for other factors and thereby derive a valid estimate for the treatment effect of a staggered board on firm value. Formally, even though $E\left[Y_{0, i} \mid D_{i}=1\right] \neq E\left[Y_{0, i} \mid D_{i}=0\right], E\left[Y_{0, i} \mid D_{i}=1, x_{i} \beta\right]$ may equal $E\left[Y_{0, i} \mid D_{i}=0, x_{i^{\prime}} \beta\right]$, permitting valid identification of the ATE.

It is unlikely that the addition of control variables solves the endogeneity bias problem. Model III demonstrates why. If heterogeneous firms choose staggered boards to maximize value, then differential staggered board choices by seemingly identical firms indicate that the firms are different. This difference could be correlated with value, implying that $E\left[Y_{0, i} \mid D_{i}=1, x_{i} \beta\right]$ $\neq E\left[Y_{0, i} \mid D_{i}=0, x_{i^{\prime}} \beta\right]$, and making inferences about the ATE derived from cross-sectional variation in staggered boards invalid. Again, regressions may find positive ATEs when there are none in truth.

It is possible that Model I or II applies after conditioning for control variables, and that variation in staggered boards or other governance features is random. Model I is plausible, but contradicts the results of most of these studies by requiring an ATE near zero. Model II would allow valid inference and generate positive ATEs. Model II, however, requires an explanation for why, after controlling for other observed variables, governance choices (1) vary randomly and (2) are systematically biased downward. Indeed, most of the studies examined here make no such argument. Many of them (e.g., Gompers, Ishii, and Metrick 2003; Bebchuk and Cohen, 2005) emphasize that the cross-sectional results prove associations rather than causation. ${ }^{9}$ Future articles should make such an argument explicitly or place reduced emphasis on their OLS findings.

If Model I or II applies after controlling for other variables, then heterogeneity of firms does not present a barrier for recovering a valid estimate of the average treatment effect on the treated. These models imply that $E\left[Y_{0, i} \mid D_{i}=1, x_{i} \beta\right]=E\left[Y_{0, i} \mid D_{i}=0, x_{i^{\prime}} \beta\right]$. Thus, $\left[E\left[Y_{i} \mid D_{i}=\right.\right.$ $\left.1]-E\left[Y_{i} \mid D_{i}=0\right]\right]=E\left[Y_{1, i}-Y_{0, i} \mid D_{i}=1\right]$, so heterogeneity of governance simply means that OLS estimates must be interpreted as average causal effects on the treated group (ATET) $\left(E\left[Y_{1, i}-Y_{0, i} \mid D_{i}=1\right]\right)$ rather than universal causal effects $\left(Y_{1}-Y_{0}\right)$.

9. The emphasis on association rather than causation, while justified, should not be overstated. The papers have attracted the attention that they have because of the possibility of causation and all the papers adduce some evidence that governance has a causal effect on firm value or performance. 


\section{Treatment Effects for Select Groups of Firms}

While the papers under study concede that endogeneity bias precludes claims about the treatment effects of governance, many claim that treatment effects can be estimated for certain subgroups of firms. The argument runs as follows. At some point, some firms made governance choices that are unrelated to the effects of these choices today. These choices then became fixed, in spite of their positive impacts. Thus, the governance choices for firms in this subsample originally corresponded to Model I, and with time they may have become like Model II, allowing for valid identification of the treatment effects of governance. For example, Bebchuk and Cohen (2005) and Bebchuk, Coates, and Subramanian (2002) argue that the staggered board choices of firms that went public long ago were chosen for some reason unrelated to the effects of staggered boards today (after controlling for other variables). Staggered boards are nearly impossible to create today. Therefore, variation in staggered boards follows Model I or Model II, implying that $E\left[Y_{0, i} \mid D_{i}=1, x_{i} \beta\right.$, mature $]=E\left[Y_{0, i} \mid D_{i}=0, x_{i^{\prime}} \beta\right.$, mature $]$ and allowing for identification of treatment effects. Daines makes a similar argument with respect to Delaware incorporation in mature firms.

There are several problems with these analyses. First, the assumption that old variations in staggered board status are exogenous with respect to today's value may simply be wrong. Presumably, old decisions were taken according to Model III. While the parameters of Model III may have changed over the intervening period, the original choice variable may be correlated with unobserved variables today.

Second, the stickiness of old decisions that creates Model II like variation today may be an inappropriate assumption. As recognized by BCS when critiquing Daines' incorporation study, firms may change their state of incorporation, implying that old decisions are not perfectly sticky. Moreover, firms that choose to change their old decision may be different than firms that do not, reintroducing Model III or Model IV like heterogeneity into the data-generating process for old firms and implying that $E\left[Y_{0, i} \mid D_{i}=1, x_{i} \beta\right.$, mature $] \neq E\left[Y_{0, i} \mid D_{i}=0, x_{i^{\prime}} \beta\right.$, mature $]$. If firms with good executives change their states of incorporation to Delaware but firms with bad executives do not, then comparing Delaware firms with non-Delaware firms may confound the effect of Delaware incorporation with the effect of having a good or bad CEO. BCS and BC argue that 
staggered boards are different than reincorporation decisions, in that adopting a staggered board was not possible in the 1990s. This may be true, but eliminating a staggered board was an option. Firms that chose to eliminate their staggered board may have been different than firms that retained their staggered board, implying that Model III or IV applies to the staggered board case as well as the reincorporation case. This concern can be dealt with using an instrumental variables specification rather than the subsample approach, as described below.

Third, even if we assume that there is no omitted variable bias correlated with choice of treatment, that is, $E\left[Y_{0, i} \mid D_{i}=1, x_{i} \beta\right.$, mature $]=$ $E\left[Y_{0, i} \mid D_{i}=0, x_{i^{\prime}} \beta\right.$, mature $]$ and $E\left[Y_{1, i}-Y_{0, i} \mid D_{i}=1, x_{i}^{\prime} \beta\right.$, mature $]$ may be validly estimated, we may not be particularly interested in this treatment effect. Old firms are different from the average firm. The effect of staggered boards on this subset of firms may be different from the treatment effect of policy interest. Suppose a state is considering a law outlawing staggered boards. In this case, the treatment effect of interest is the ATET, $E\left[Y_{1, i}-Y_{0, i} \mid D_{i}=1\right] . \quad E\left[Y_{1, i}-Y_{0, i} \mid D_{i}=1, x_{i}^{\prime} \beta\right.$, mature $]$ may be a bad estimate of this quantity. Old firms have already survived and avoided becoming part of another firm for a long period. If the primary effect of a staggered board is to reduce the probability of takeover, then the effect of a staggered board on firms less likely to get taken over and more likely to take other firms over should be quite different than the average effect of a staggered board on all firms with a staggered board. The subsample approach may therefore give us valid estimates of treatment effects that have little policy relevance. Future research should discuss the plausibility of extrapolating the results from population subsamples with valid treatment effect estimates to the primary population of interest. For example, similar observable variable values for both the population of interest for policy and the subsample with valid estimates would enhance the plausibility of extrapolation (Imbens, 2007a).

\section{Fixed Effects}

A similar critique can be directed at another means of identification of treatment effects - using fixed effects. Fixed-effect specifications identify the treatment effects of governance from changes in governance within a given firm. The value of Delaware incorporation, for example, may be identified from companies that switch from another state to Delaware 
(Romano, 1985). This mitigates the endogeneity effect, since other firm characteristics are held constant. Generally, we would expect $E\left[Y_{0, i} \mid D_{i}=1\right]$ $=E\left[Y_{0, i} \mid D_{i}=0\right]$, since it is the same firm that is being compared with itself $^{10}$ (Chi, 2005 ${ }^{11}$ ). In this case, we obtain an estimate of the treatment effect of DE reincorporation for these firms, $E\left[Y_{1, i}-Y_{0, i} \mid\right.$ reincorporate $]$. If we want to estimate the effect of having all corporations adopt DE law, however, then the treatment-effect estimate we obtain may be different than the treatment effect we desire, which is $E\left[Y_{1, i}-Y_{0, i} \mid D_{i}=0\right]$. Firms that reincorporate have chosen to do so, presumably because they think that DE law will increase value. Thus, we accurately estimate the treatment effect from a fixed-effects estimation, $E\left[Y_{1, i}-Y_{0, i} \mid\right.$ reincorporate $]=$ $E\left[Y_{1, i}-Y_{0, i} \mid Y_{1, i}>Y_{0, i}\right]$. Even if reincorporation is not associated with any other information, reincorporation studies will find a higher average estimated treatment effect than the one most useful for policy, because the firms that choose to reincorporate are likely to have a higher average benefit than firms that do not, even if those firms are similar along every observable dimension. This is an example of what Heckman, Urzua, and Vytlacil (2006) call essential heterogeneity, where the probability of receiving the treatment is correlated with the treatment's effect after controlling for observables.

\section{Instrumental Variables}

Assuming that Models I or II do not perfectly describe the governance data-generating process after conditioning on other variables or examining subsets of variables, it is extremely difficult to obtain valid treatment-effect estimates of governance. It is not impossible, however. If some factor, often called an instrument, changes governance according to Models I or II and this factor does not impact the value of a firm in any other way, then the treatment effects of a change in governance can be estimated by focusing on the changes in governance associated with Model I or Model II like sources.

10. Bebchuk, Cohen, and Ferrell 2002 argue that $E\left[Y_{0, i} \mid D_{i}=1\right] \neq E\left[Y_{0, i} \mid D_{i}=\right.$ $0]$, because there are often confounding factors that take place at the same time as reincorporation announcements that impact the value of firms.

11. Chi uses fixed-effects methods in combination with Granger causality methods to argue that governance causes changes in value, and not vice versa. While suggestive, the fact that changes in governance precede changes in value does not prove causality, because managers with superior information may alter governance before revealing information would cause value to change. 
If, for example, we assume that some random factor called $Z_{i}{ }^{12}$ (e.g., a coin flip) raises the probability that a firm will have a staggered board, then we can easily estimate the average treatment effect of the coin flip.

Valid instruments are very difficult to find, particularly in the corporate governance context, as emphasized by Gompers, Ishii, and Metrick (2003) and Bhagat and Jeffries (2003). The instruments that are valid may suffer from the weak instruments problem. ${ }^{13}$ Let us assume, however, that a valid instrument may be found that does not suffer from the weak instruments problem. While neither the Daines study of Delaware incorporation nor the Bebchuk and Cohen study of staggered boards advocate this point, the old governance choices of a firm may be an instrument for its current governance choices. That is, the old governance (e.g., staggered board) choice of a firm may have been effectively random from the perspective of today's value, $E\left[Y_{0, i} \mid\right.$ historical $\left.D_{i}=1\right]=E\left[Y_{0, i} \mid\right.$ historical $\left.D_{i}=0\right]$ and may still have an effect on some firms' governance choices due to inertia. Rather than simply running OLS on a subsample of mature firms, which assumes that $E\left[Y_{0, i} \mid\right.$ present $\left.D_{i}=1\right]=E\left[Y_{0, i} \mid\right.$ present $\left.D_{i}=0\right]$ and raises the possibility of confounding exogenous sources of variation in governance with endogenous sources of variation, such as a firm's current decision to stick with or alter its current governance choice, we can use old governance choices as an instrument (historical $D_{i}$ can be treated as $Z_{i}$ ) for current governance choices and estimate thereby isolating the exogenous variation from Model I or II like sources. In other words, the Daines and Bebchuk and Cohen intuition about the value of focusing on old firms is on target, but their empirical execution of this intuition (subsample OLS rather than IV) is flawed. With homogeneous effects of historical governance choices on current governance choices, we would estimate the treatment effect of a staggered board or Delaware incorporation, $\alpha$ as follows:

$$
\begin{aligned}
\alpha= & \left\{E\left[Y_{i} \mid \text { historical }_{i}=1\right]-E\left[Y_{i} \mid \text { historical }_{i}=0\right]\right\} / \\
& \left\{E\left[D_{i} \mid \text { historical }_{i}=1\right]-E\left[D_{i} \mid \text { historical } D_{i}=0\right\} .\right.
\end{aligned}
$$

12. Again, a discrete instrument is used for simplicity.

13. Bound, Jaeger, and Baker (1996) show that instrumental variable standard error estimates are often underestimated. The underestimation is particularly severe when there are many instruments that are weakly correlated with the endogenous variable (Imbens, 2007b). 
Other studies of governance have also used instruments. For example, let us assume that the corporate governance instrument used by Black, Jang, and Kim (2006) in their study of the impact of Korean corporate governance on firm performance is a valid instrument. (BJK note that Korea introduced some corporate governance requirements for large firms above a fixed value, but not for smaller firms below this value. They use this cutoff value to instrument for governance.)

Instrumental variables and heterogeneity. With homogeneous treatment effects, a IV $(\alpha)$ estimator provides a valid estimate of the treatment effect. If the effect of an instrument, such as historical governance choice, is different for different firms, however, then the IV estimator does not provide an estimate for the average effect of governance (ATE or ATET) on performance. That does not mean that instrumental variables cannot yield interpretable estimates in the presence of heterogeneity, however. As shown by Imbens and Angrist (1994), under certain assumptions ${ }^{14}$ IV estimates with heterogeneous treatment effects can be interpreted as weighted averages of the individual causal effects, where the weights are determined by the impact of the instrument on the probability that an individual receives the treatment. The effect of the treatment for subjects whose probabilities of receiving treatment are heavily influenced by the instrument receives greater weight in the IV estimate than other individuals' effects. Imbens and Angrist call this parameter the local average treatment effect (LATE). ${ }^{15}$ In a series of papers, Heckman, Vytlacil and coauthors $(2001,2005,2006)$ expand these insights in a number of directions. They demonstrate (Vytlacil, 2002) that the LATE model is equivalent to a selection model under many conditions, that LATE is a discrete approximation to the MTE (Heckman and Vytlacil, 2005; Heckman, Urzua, and Vytlacil, 2006) and develop a technique called local instrumental variables that identifies marginal treatment effects (Heckman and Vytlacil, 2005; Heckman, Urzua, and Vytlacil, 2006).

Applying these insights to studies of governance yields a number of important conclusions. Due to essential heterogeneity, firms that would be

14. The most important assumption for defining the meaning of LATE is monotonicity - the direction of the effect of the instrument on the probability of receiving treatment is the same for all individuals (Imbens, 2007a).

15. Vytlacil (2002) shows that under some conditions, selection models are equivalent to LATE. 
greatly affected by staggered boards or Delaware incorporation are likely to select into their desired treatment even after controlling for other variables. Using old governance choices as an instrument for governance today, assuming that the old governance choice is truly exogenous from today's perspective, will return the effect of governance for firms whose governance choices are highly affected by the old governance choice. These firms are likely to respond less dramatically to a change in staggered board status or Delaware incorporation than the average firm. ${ }^{16}$ Thus, the LATE estimator or its MTE via local IV regression analogue will yield estimates of smaller magnitude than the ATE or ATET. Similarly, the BJK instrument estimates the value of governance for companies near the cutoff point for governance requirements that would not have had governance were it not for the fact that the law required some of them to. Assuming that there is some correlation between firm choices and the efficient choice, the MTE (or discrete LATE approximation) of the required governance for these firms will be lower than the ATE or ATET.

These LATE or MTE estimates may or may not be the best guides for policy (Heckman, 2001). The treatment effect for a firm whose staggered board status is affected by old governance choice (the treatment effect recovered by the LATE estimate) is not representative of the treatment effect for a firm that will change its staggered board status if staggered boards are outlawed. However, the treatment effect for a firm whose staggered board status is affected by old governance choice is representative of the treatment effect for a firm that might change its staggered board status in response to small subsidy for elimination of a staggered board.

Heckman and Vytlacil (2001) suggest the following procedure in the presence of heterogeneity. First, the impact of a proposed policy on the distribution of a treatment variable should be estimated. For example, if a state is considering a fee for staggered board, then there will be fewer companies with staggered boards. The higher the fee, the greater the change in the distribution. Once this is calculated, Heckman and Vytlacil recommend that the researcher should calculate the effect of the policy on the outcome of interest

16. This will be true if governance choices are modeled according to Model I or Model II/Model IV, so long as firm choices of governance have at least some correlation to the efficient choices. Note that in Model II/Model IV, this correlation can exist but all firms may still systematically over or underestimate the impacts of governance. 
using the MTEs obtained from local instrumental variables estimates. In the staggered board case, the MTE (marginal treatment effect of staggered boards on value or takeover probability) for firms whose staggered board status will shift with the fee provides the best indication of the impact of the policy on corporate value.

\section{Conclusion}

So what does all this modeling effort and talk of heterogeneous treatment effects law buy us? In my opinion, quite a bit. On the one hand, it forces us to be more modest in our conclusions. No single paper, even one that produces valid inferences and overcomes endogeneity, will ever solve the question of the effect of staggered boards on corporate value. Finding that staggered boards increase or decrease value for old companies that have not found it worthwhile to change their staggered board status does not mean that staggered boards are good for value for all firms or for no firms.

The flip side of this modesty is the possibility of the accumulation of policy wisdom. Modest demonstrations of local average treatments effects are much more likely to be convincing than supposed demonstrations of the global effects of corporate governance. Instead of a never-ending cycle of papers proving the absolute efficiency or inefficiency of staggered boards that suffer from the endogeneity of Model III, we may get a series of papers demonstrating the local treatment effects of staggered boards in various contexts.

Following Heckman and Vytlacil (2001), scholars and policymakers should pursue these steps. (1) Identify the type of firms that are to be affected by a proposed corporate governance intervention. (2) Determine whether endogeneity concerns along the lines of Models III and IV preclude the estimation of treatment effects from ordinary regressions of groups of firms. (3) In the unlikely event that there are no endogeneity concerns, then policy conclusions can be drawn from these studies, though these conclusions should carefully distinguish different treatment effects and identify the treatment effect that is most relevant for the group of firms affected by the proposed intervention. (4) If endogeneity is a concern, then an instrument that creates random variation in corporate governance choices for these types of firms should be found. If such an instrument is available, then the LATE or MTE estimates from a IV study can reasonably be extrapolated to the 
proposed policy intervention. If not, then more studies are desirable. (5) If a number of LATE estimates for different subsets of firms reveal a consistent treatment effect pattern for a corporate governance intervention, then extrapolation from these local-effect estimates to general policies is justified.

\section{References}

Angrist, Joshua. 2007. "Treatment Effects". The New Palgrave Dictionary of Economics. New York: Palgrave Macmillan.

Bebchuk, Lucian Arye, John C. Coates IV, and Guhan Subramanian. 2002. "The Powerful Antitakeover Force of Staggered Boards: Theory, Evidence, and Policy," 54 Stanford Law Review 887.

Bebchuk, Lucian, and Alma Cohen. 2005. "The Costs of Entrenched Boards" 78 Journal of Financial Economics 409-33.

Bebchuk, Lucian, Alma Cohen, and Allen Ferrell. 2002. "Does the Evidence Favor State Competition in Corporate Law?" 90 University of California Law Review. 1775-1821.

Bebchuk, Lucian Arye, Alma Cohen, and Allen Ferrell. 2004. "What Matters in Corporate Governance?" (September 2004). Harvard Law School John M. Olin Center Discussion Paper No. 491. Available at SSRN: http:// ssrn.com/abstract=593423, doi: 10.2139/ssrn.593423.

Bhagat, Sanjai, and Bernard Black. 2002. "The Non-Correlation between Board Independence and Long-Term Firm Performance" 27 Journal of Corporation Law 231.

Bhagat, Sanjai, and Richard H. Jefferis, Jr. 2003. The Econometrics of Corporate Governance Studies. Cambridge, MA: MIT Press.

Black, Bernard, H. Jang, and W. Kim. 2006. "Does Corporate Governance Affect Firm Value? Evidence from Korea" 22 Journal of Law, Economics and Organization 366.

Bound, J., A. Jaeger, and R. Baker. 1996. "Problems with Instrumental Variables Estimation When the Correlation Between the Instruments and the Endogenous Explanatory Variable is Weak" 90 Journal of the American Statistical Association 443-50.

Chi, Jianxin. 2005. "Understanding the Endogeneity Between Firm Value and Shareholder Rights" 34 Financial Management 65-76.

Core, John, Wayne R. Guay, and Tjomme O. Rusticus. 2006. "Does Weak Governance Cause Weak Stock Returns? An Examination of Firm Operating Performance and Investors' Expectations" 61 Journal of Finance 655-87.

Cremers, K. J. Martijn, and Vinay B. Nair. 2005. "Governance Mechanisms and Equity Prices" 60 Journal of Finance 2859-94.

Daines, R. 2001. “Does Delaware Law Improve Firm Value?” 62 Journal of Financial Economics 525-58. 
Eisenberg, Theodore, Stefan Sundren, and Martin Wells. 1998. "Larger Board Size and Decreasing Firm Value in Small Firms" 48 Journal of Financial Economics $35-54$.

Gompers, Paul, Joy Ishii, and Andrew Metrick. 2003. "Corporate Governance and Equity Prices," 118 Quarterly Journal of Economics 107-55.

Heckman, J. 2001. "Micro Data, Heterogeneity, and the Evaluation of Public Policy: Nobel Lecture," 109 Journal of Political Economy 673-748.

Heckman, J., S. Urzua, and E. Vytlacil. 2006. "Understanding Instrumental Variables in Models with Essential Heterogeneity" 88 Review of Economics and Statistics 389-432.

Heckman, J., and E. Vytlacil. 2001. "Policy Relevant Treatment Effects" 91 American Economic Review 107-11.

Heckman, J., and E. Vytlacil. 2005. "Structural Equations, Treatment Effects and Econometric Policy Evaluation" 73 Econometrica 669-738.

Imbens, G. 2007a. "Instrumental Variables with Treatment Effect Heterogeneity: Local Average Treatment Effects." Lecture 5: Whats New in Econometrics. Available at http://www.nber.org/ confer/2007/si2007/ wneprg.html.

Imbens, G. 2007b. "Weak Instruments and Many Instruments," Lecture 13: Whats New in Econometrics. Available at http://www.nber.org/ confer/2007/ si2007/wneprg.html.

Imbens, G., and J. Angrist. 1994. "Identification and Estimation of Local Average Treatment Effects," 62 Econometrica 467-75.

Petersen, Mitchell A. 2008. "Estimating Standard Errors in Finance Panel Data Sets: Comparing Approaches," Review of Financial Studies forthcoming.

Romano, Roberta. 1985. "Law as a Product: Some Pieces of the Incorporation Puzzle," 1 Journal of Law, Economics and Organization 225.

Subramanian, Guhan. 2004. "The Disappearing Delaware Effect" 20 Journal of Law, Economics and Organization 32.

Vytlacil, E. 2002. "Independence, Monotonicity, and Latent Index Models: An Equivalence Result" 70 Econometrica 331-41. 